\title{
Surface Characterization of Secondary Organic Aerosols from Ozonolysis of Monoterpene and the Effects of Acute Lung Injury in Mice
}

\author{
Xinyi Niu', Yu Huang 2,3*, Shun Cheng Lee ${ }^{4}$, Jian $\mathrm{Sun}^{5}$, Kin Fai Ho ${ }^{1 *}$ \\ ${ }^{1}$ The Jockey Club School of Public Health and Primary Care, The Chinese University of Hong Kong, Hong Kong, China \\ ${ }^{2}$ Key Lab of Aerosol Chemistry \& Physics, Institute of Earth Environment, Chinese Academy of Sciences, Xi'an 710075 , \\ China \\ ${ }^{3}$ State Key Lab of Loess and Quaternary Geology (SKLLQG), Institute of Earth Environment, Chinese Academy of \\ Sciences, Xi'an 710061, China \\ ${ }^{4}$ Department of Civil and Environmental Engineering, The Hong Kong Polytechnic University, Hong Kong, China \\ ${ }^{5}$ School of Human Settlements and Civil Engineering, Xi'an Jiaotong University, Xi'an 710049, China
}

\begin{abstract}
Monoterpene is a biogenic volatile organic compound commonly found in cleaning products and air fresheners. It can react rapidly with indoor oxidants, such as ozone $\left(\mathrm{O}_{3}\right)$, to produce secondary organic aerosols (SOAs) in indoor environments, and the reactions are potentially influenced by ammonia $\left(\mathrm{NH}_{3}\right)$. This study simulated the reactions of $\mathrm{O}_{3}$ and monoterpene with and without the presence of $\mathrm{NH}_{3}$ in an environmental chamber and investigated the surface characterization (elemental components and carbon states) of the $\mathrm{PM}_{2.5}$ generated by these reactions. We found that the generated particles possessed a higher content of nitrogen-containing organic compounds when $\mathrm{NH}_{3}$ was present. Unsubstituted aromatic carbon and aliphatic carbon were the main carbon structures, exhibited by over $60 \%$ of the carbon-containing compounds. Additionally, in the presence of $\mathrm{NH}_{3}$, more amide carbon and carboxylic carbon formed during the reactions. We also examined acute lung injury in mice caused by new particle formation under different reaction conditions. Oxidative stress was observed in the bronchoalveolar lavage fluid of the mice, as evidenced by a decrease in antioxidant enzymes (superoxide dismutase) and

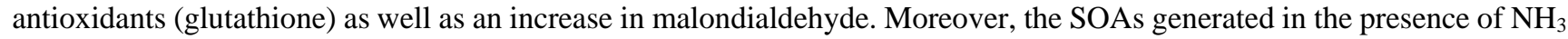
lowered glutathione levels, indicating a rise in oxidative stress. Hence, fine particles formed by indoor oxidative reactions may trigger acute lung injury in humans, potentially causing further respiratory disease.
\end{abstract}

Keywords: Indoor air pollution; SOA; Oxidative stress; Acute lung injury.

\section{INTRODUCTION}

Secondary organic aerosols (SOAs), mainly generated from the oxidative reactions of unstable chemical compounds (i.e., volatile organic compounds [VOCs]) in the atmosphere, account for a considerable proportion of organic aerosols in the urban atmosphere (Hallquist et al., 2009). The chemical characteristics of SOAs generated in indoor environments are different from those generated outdoors as a result of divergent emission sources and formation processes (Colbeck et al., 2010; Perrino et al., 2016). The organic compounds generated indoors can substantially contribute to personal $\mathrm{PM}_{2.5}$ (particulate matter in diameter $<2.5 \mu \mathrm{m}$ ) exposure owing to the long exposure time in indoor environments (Morawska et al., 2013). Epidemiological and toxicological

\footnotetext{
* Corresponding author.

Tel.: +852 22528763; Fax: +852 26063500
}

E-mail address: kfho@cuhk.edu.hk

studies have confirmed the association between $\mathrm{PM}_{2.5}$ and damage to human pulmonary and cardiovascular systems (Kappos et al., 2004; Kim et al., 2015). Although SOAs contain many toxic compounds (i.e., metals, polycyclic aromatic hydrocarbons [PAHs] and carbonyls), evidence for their adverse effects on the human respiratory system is still limited (McDonald et al., 2012).

Ozone $\left(\mathrm{O}_{3}\right)$ is a common initiator of indoor gas-phase oxidation. It was estimated that average daily indoor intake of ozone oxidation products was one-third to two times compared to that from outdoor ozone inhalation (Weschler, 2006). Biogenic volatile organic compounds (BVOCs) are also common indoor pollutants. $\mathrm{O}_{3}$ and BVOCs can react to and initiate most indoor chemical reactions (Matsumoto, 2014). The presence of unsaturated carbon double bonds within the molecular structures of BVOCs makes these compounds highly reactive with indoor oxidants, eventually leading to the formation of various secondary pollutants (Yuan et al., 2013). Hydroxyl radicals $(\mathrm{OH})$ and nitrate radicals 
$\left(\mathrm{NO}_{3}\right)$ can also result in the formation of SOAs (Wang et al., 2016). BVOCs are present at high concentrations in indoor environments due to the use of cleaning products and air fresheners (Huang et al., 2011). The most common indoor terpenoids are monoterpenes; d-limonene, for example, can react rapidly with ozone and has high particle formation potential (Nørgaard et al., 2014). The formation of ultrafine particles produced by ozone and limonene reactions was observed in indoor air under low and closed ventilation conditions, and it was revealed that excess $\mathrm{O}_{3}$ led to higher particle concentrations (Langer et al., 2008). Indoor gasphase reactions can be affected by various factors in real indoor environments, including temperature, relative humidity and concurrent gaseous pollutants. $\mathrm{NH}_{3}$ is one of the important indoor gaseous pollutants, mainly emitted from household cleaners, refrigeration units and addition urea-based antifreeze admixtures (Pei et al., 2016). $\mathrm{NH}_{3}$ can interact with gasphase organic acids, which are the major products of indoor BVOC reactions, to form condensable salts, thereby enhancing SOA formation ( $\mathrm{Na}$ et al., 2007).

Particulate matter suspended in the atmosphere can be effectively deposited in the extrathoracic airways, whereas $\mathrm{PM}_{2.5}$ or PM of a smaller size can easily pass through the respiratory tract to the alveoli. These particles penetrate deeper into the airways and alveoli and undergo a slow clearance process, with particles usually remaining for weeks or months (Kim and Hu, 1998). PM-mediated oxidative stress through the generation of reactive oxygen species (ROS) is considered a crucial molecular mechanism of PM- induced toxicity (Shen and Anastasio, 2011). Oxidative stress refers to a critical imbalance between ROS production during oxidative phosphorylation and antioxidant defense, and ROS has been identified as signaling molecules in regulating pathways (Deng et al., 2013). Riva et al. (2011) revealed that acute exposure to low doses of $\mathrm{PM}_{2.5}$ could induce lung inflammation and oxidative stress in a dose-dependent manner in mice. Generally, the adverse effect of $\mathrm{PM}_{2.5}$ is determined by its surface characterization and chemical composition (Daher et al., 2014; Niu et al., 2017). Studies have reported that $\mathrm{PM}_{2.5}$ chemical compounds including aliphatic and chlorinated hydrocarbons, PAHs and alkyl derivatives, ketones, and quinones are responsible for the formation of oxidative stress and inflammation through the generation of free radical species (Oh et al., 2011; Yi et al., 2014; Ho et al., 2016b).

The chemical states of carbon and nitrogen and their atomic concentrations in PM critically determines their impact on human health due to their specific surface areas (Cheng et al, 2013). SOAs are important $\mathrm{PM}_{2.5}$ components contributing to numerous health effects including increased respiratory symptoms, exacerbation of chronic respiratory and cardiovascular diseases, and decreased lung function (Kim et al., 2015). Therefore, it is crucial to study the characteristics of SOAs' functional groups and the related adverse health effects from $\mathrm{O}_{3}$ and monoterpene reactions. Most previous studies on $\mathrm{PM}_{2.5}$ health effects were focused on ambient $\mathrm{PM}_{2.5}$ or specific air pollution sources (Dieme et al., 2012; Chuang et al., 2013; Dilger et al., 2016; Ho et al., 2016a). An environmental chamber can be used to simulate the formation of SOAs in the atmosphere, and the surface characterization of SOAs collected can be determined and used for toxicity experiments. The objective of this study is to (1) identify the surface characterization (main elemental composition and carbon states) of SOAs formed in the reactions of $\mathrm{O}_{3}$ and monoterpene, (2) investigate the variations of functional groups of SOAs in the reactions with and without $\mathrm{NH}_{3}$, and (3) evaluate the oxidative potential in the respiratory system caused by SOAs generated from $\mathrm{O}_{3}$ and monoterpene reactions.

\section{METHODS}

\section{Chamber Study}

An environmental chamber with an effective volume of $18.26 \mathrm{~m}^{3}(3.2 \mathrm{~m} \times 3.2 \mathrm{~m} \times 2.5 \mathrm{~m})$ were used for the simulation experiments of SOA generation. Details of the chamber can be found in Huang et al. (2012). Prior to use, the interior surfaces of the chamber were thoroughly cleaned and conditioned for 4 hours at the desired physical conditions with the air exchange rate $(\mathrm{ACH})$ of $0.36 \mathrm{~h}^{-1}$, relative humidity $(\mathrm{RH})$ of $75 \%$, and temperature of $23^{\circ} \mathrm{C}$. The background level of total volatile organic compounds (TVOCs) and individual VOCs were below $10 \mu \mathrm{g} \mathrm{m}^{-3}$ and $2 \mu \mathrm{g} \mathrm{m}^{-3}$, respectively, in each experiment. $d$-Limonene, as a common monoterpene, was chosen for this study. To reach an initial BVOC concentration of approximately $200 \mathrm{ppb}$ in the chamber, $60 \mu \mathrm{L}$ of d-limonene was introduced to the chamber using a 40-L air bag (Tedlar; SKC Inc., Eighty Four, PA, USA). The air bag with zero air generated from a Zero Air Supply (Model 111; Thermo Environmental Instruments) was injected with d-limonene using a $100-\mu \mathrm{L}$ syringe (Hamilton, Reno, NV, USA). After complete vaporization, the gas-phase d-limonene was introduced into the chamber by an AirChek sampler (Model 224-44XR; SKC Inc.) at a flow rate of $1 \mathrm{~L} \mathrm{~min}^{-1}$. Before the d-limonene introduction, ozone was introduced into the chamber using an ozone generator (Model 2001; Jelight Company Inc., Irvine, CA, USA) at a constant flow rate of $63 \mathrm{~mL} \mathrm{m^{-1 }}$ to approximately $70 \mathrm{ppb}$. After $30 \mathrm{~min}$, the gaseous d-limonene prepared in the sampling bag was injected. The $\mathrm{O}_{3}$ supply was terminated 120 min after the injection of d-limonene. In the $\mathrm{NH}_{3}$ experiments, $\mathrm{NH}_{3}$ was introduced to the chamber $30 \mathrm{~min}$ before the introduction of $\mathrm{O}_{3}$. The $\mathrm{NH}_{3}$ was supplied from a compressed gas cylinder at a concentration of 1000 ppm ( $\mathrm{N}_{2}$ balance, 99.999\%; BOC Gas, UK). $\mathrm{NH}_{3}$ was measured by a thermal oxidizer (Thermal Converter Model 501; Teledyne API) and detecting the oxidized ammonia as NO (Chemiluminescence $\mathrm{NH}_{3}$ Analyzer Model 201A; Teledyne API). Each experiment was repeated three times to demonstrate reproducibility.

\section{SOA Sampling}

Two mini-volume samplers (Airmetrics, Springfield, OR, USA) with a flow rate of $5 \mathrm{~L} \mathrm{~min}^{-1}$ were used for $\mathrm{PM}_{2.5}$ collection in the environmental chamber during $\mathrm{O}_{3}$ and d-limonene reactions. The samplers were turned off at the beginning of the experiments. The sampling inlets were placed at $\sim 1.2 \mathrm{~m}$ above ground level. The $\mathrm{PM}_{2.5}$ samples were collected on 47-mm quartz filters (Whatman, Germany). 
The filters were preheated at $900^{\circ} \mathrm{C}$ for $3 \mathrm{~h}$ to reduce the amount of organic vapors. All filters were equilibrated at a condition of $\sim 50 \% \mathrm{RH}$ and $\sim 23^{\circ} \mathrm{C}$ for over $48 \mathrm{~h}$ prior to weighing. Before and after sampling, each filter was weighed at least twice on a microbalance (M5; Sartorius, Göttingen, Germany). The precision was $<15 \mu \mathrm{g}$ per filter before sampling and $<20 \mu \mathrm{g}$ after sampling. The exposed filters were stored in a refrigerator at $\sim 4^{\circ} \mathrm{C}$ until the chemical analysis was conducted to prevent the evaporation of volatile compounds. Operation blank samples were processed in two groups of background experiments.

\section{X-ray Photoelectron Spectroscopy Analysis}

The particles on the filter surface, consisting of the elements and their bonding states, from $\mathrm{O}_{3}$ and d-limonene reactions were analyzed using X-ray photoelectron spectroscopy (XPS) in the spectrometer (Thermo Fisher Scientific, Waltham, MA, USA) equipped with a monochromatic Al K $\alpha$ X-ray source $(1486.6 \mathrm{eV})$. XPS has been used as a usual method for surface analysis, which can provide information on elemental contributions. Chemical states of elements can also be determined by peak synthesis. Samples can be directly examined by XPS without any sample preparation. The $\mathrm{PM}_{2.5}$ samples were punched from the 47-mm filters with an area of $0.526 \mathrm{~cm}^{2}$. High-resolution spectra were collected at a resolution of $0.2 \mathrm{eV}$ for binding energy, $100 \mathrm{~ms}$ per step and $20.0 \mathrm{eV}$ pass energy. All peaks were referenced to the $\mathrm{C} 1 \mathrm{~s}$ binding energy for adventitious carbon at $284.8 \mathrm{eV}$. Elements oxygen $(\mathrm{O})$, silicon $(\mathrm{Si})$, carbon $(\mathrm{C})$, sodium $(\mathrm{Na})$, and nitrogen $(\mathrm{N})$ were identified from the spectra.

\section{Animal Exposure to PM2.5}

Male Kunming mice (20-25 g) were purchased from the Experimental Animal Center, Xi'an Jiaotong University (Xi'an, China). They were maintained under standard conditions with $\sim 50 \% \mathrm{RH}, \sim 23^{\circ} \mathrm{C}$, and a 12-h light/dark cycle. Animals were allowed free access to standard laboratory food and water. All experimental handling and safety procedures were in accordance with National Institute of Health guidelines.

All filter samples were extracted with distilled deionized water through ultrasonication to a final concentration of $50 \mu \mathrm{g} \mathrm{mL} \mathrm{m}^{-1}$. A total of 48 mice were randomly divided into four groups with 12 mice in each group, and then treated using intranasal instillation with $100 \mu \mathrm{L}$ of different solutions: (i) experimental control (control) treated with autoclaved phosphate-buffered saline (PBS) solution, (ii) field blank (blank) treated with suspension liquid from the blank samples, (iii) reaction in the absence of $\mathrm{NH}_{3}$ (without $\mathrm{NH}_{3}$ ) treated with $\mathrm{PM}_{2.5}$ extractions collected without $\mathrm{NH}_{3}$ reaction, and (iv) reaction with the presence of $\mathrm{NH}_{3}$ (with $\mathrm{NH}_{3}$ ) treated with $\mathrm{PM}_{2.5}$ extractions collected through an $\mathrm{NH}_{3}$ reaction. The mice were immobilized in a $60^{\circ}$-inclined supine position and the extractions were delivered in a dropwise manner to the nares using an automatic pipette.

Collection and Analysis of Bronchoalveolar Lavage Fluid After intranasal stimulation for 6 and $12 \mathrm{~h}$, the bronchoalveolar lavage fluid (BALF) was collected repeatedly three times using a tracheal cannula with autoclaved PBS. Each sample was instilled up to a total volume of $1.3 \mathrm{~mL}$. The recovery rate of BALF was approximately $90 \%$. The collected BALF was immediately centrifuged at $1500 \mathrm{rev} \mathrm{min}^{-1}$ for $10 \mathrm{~min}$ at $4{ }^{\circ} \mathrm{C}$ and the supernatants were collected for further analysis.

The superoxide dismutase (SOD) activity in the supernatant sample was determined using commercial SOD kits following the manufacturer's instructions. The supernatant was measured by a microplate reader (Molecular Devices, Sunnyvale, CA, USA) at an absorbance of $450 \mathrm{~nm}$. The BALF malondialdehyde (MDA) level of mice was determined by the thiobarbituric acid (TBA) method using a TBARS Assay Kit. The absorbance of the supernatant was measured at $532 \mathrm{~nm}$, and the standard curve was obtained using 1,1,3,3-tetramethoxypropane. The glutathione (GSH) level was determined using the standard method explained by Moron et al. (1979). The absorbance of the supernatant was measured at $412 \mathrm{~nm}$ and compared with the GSH standard. The kits for SOD, MDA and GSH were purchased from Jiancheng Bioengineering Institute (Nanjing, China).

\section{Statistical Analysis}

All statistical analyses were performed using SPSS software (version 21.0; IBM, New York, NY, USA). Oneway analysis of variance (ANOVA) was conducted to evaluate statistical significance between groups. A p value of $<0.05$ was considered to represent statistical significance.

\section{RESULTS AND DISCUSSION}

\section{Surface Characterization of SOAs}

The average $\mathrm{PM}_{2.5}$ mass concentrations from the reaction of $\mathrm{O}_{3}$ and monoterpene were $257.9 \pm 19.9 \mu \mathrm{g} \mathrm{m}^{-3}$ and $172.9 \pm$ $3.8 \mu \mathrm{g} \mathrm{m}^{-3}$ with and without the presence of $\mathrm{NH}_{3}$, respectively. A substantial increase was observed in SOA generation in the reaction with $\mathrm{NH}_{3}$, which indicated the positive effect of $\mathrm{NH}_{3}$ on $\mathrm{O}_{3}$ and monoterpene reactions. These results agreed with the study of Waring and Siegel (2013), which investigated the contribution to gas-phase SOA formation of ozone reactions with surface-sorbed d-limonene and demonstrated that surface reactions promoted nucleation more than gasphase reactions.

XPS survey scan was used to identify the elements on the surface of SOAs generated from $\mathrm{O}_{3}$ and monoterpene reactions. The XPS survey spectra were collected at an intensity of $1100 \mathrm{eV}$ for three particle samples (Fig. 1), including a blank filter. Fig. 2 presents the distinct elemental surface composition distributions of SOAs derived from the different conditions of $\mathrm{O}_{3}$ and monoterpene reactions. Atomic compositions for each sample were calculated using narrow-scan peak areas and the appropriate sensitivity factors for each element (Atzei and Rossi, 2004). Carbon was the third most prominent element on the filter surface (approximately 10.6-13.4\%), which is representative of the normal composition of organic matter existing in filters, and new organic aerosols also formed during the reactions of ozone and monoterpene. Only $0.6-2.3 \%$ of $\mathrm{N}$ was observed on the surface of the filter; a large proportion of $\mathrm{N}$ was generated from the organic matter 

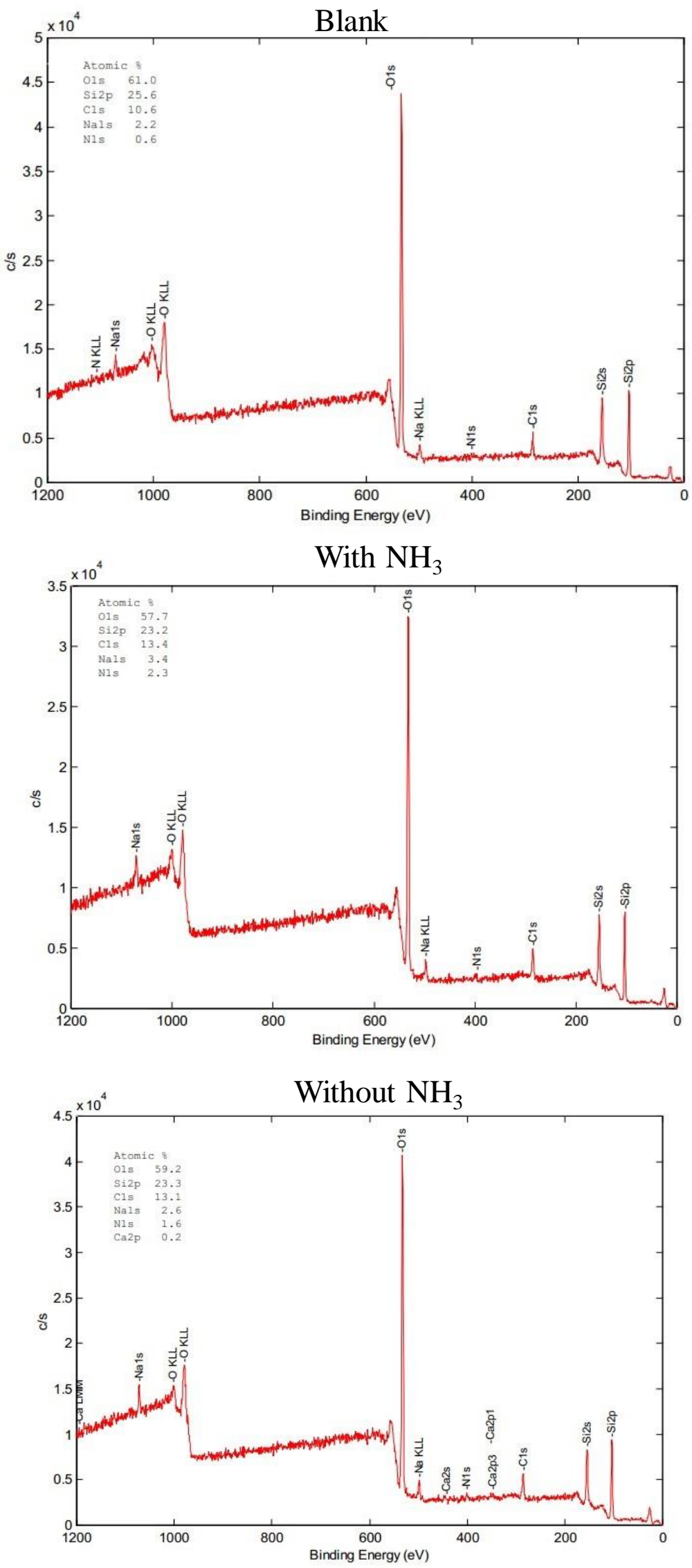

Fig. 1. XPS survey spectra for SOAs on the blank sample; sample with and without $\mathrm{NH}_{3}$ present in $\mathrm{O}_{3}$ and monoterpene reactions. 


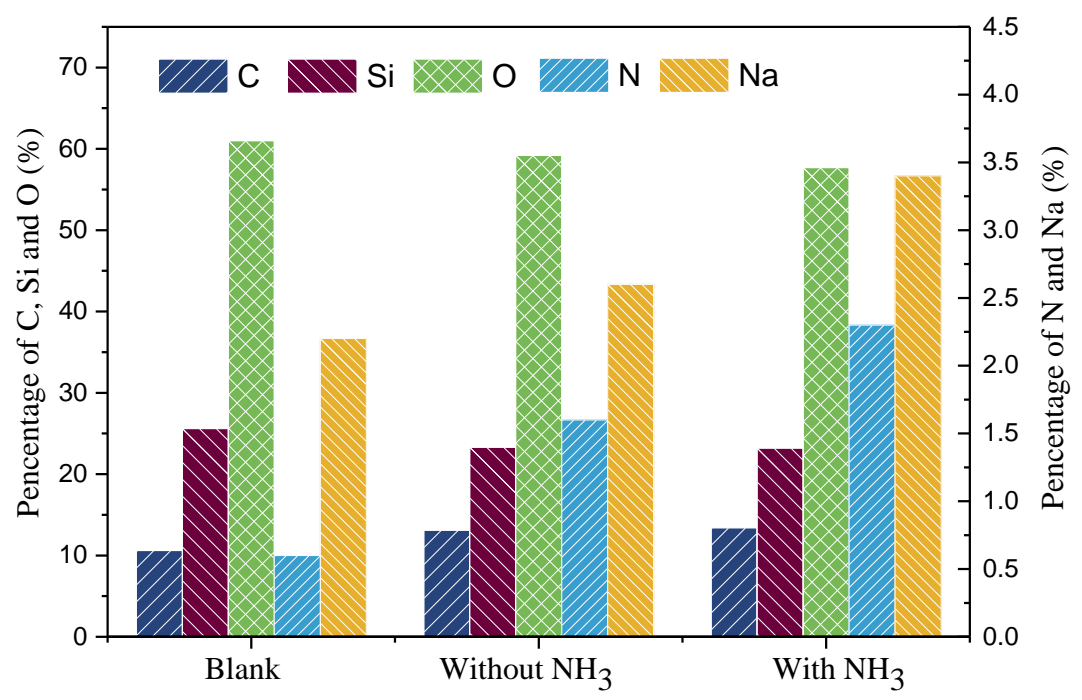

Fig. 2. Elemental distribution of SOAs generated from different conditions of $\mathrm{O}_{3}$ and monoterpene reactions.

that formed during the reaction of ozone and monoterpene. The increase of $\mathrm{N}$ indicated the transformation of gas-phase $\mathrm{N}$ (i.e., $\mathrm{NO}, \mathrm{NO}_{2}, \mathrm{~N}_{2} \mathrm{O}_{5}, \mathrm{HNO}_{3}, \mathrm{HONO}$, alkyl nitrates, and PAN) to solid phase with new formation of organic particles in the reactions.

Secondary pollutants were generated in the process of reaction, with the main element being $\mathrm{C}$ (Coleman et al., 2008). In addition, $\mathrm{O}_{3}$ and monoterpene reactions produced hydroxyl radical, which triggered further reactions with the organics generated; therefore, more carbon-constituted aerosols were generated (Chen and Hopke, 2010). When $\mathrm{NH}_{3}$ was involved in the reaction, the atomic carbon composition of carbon was slightly $(2.3 \%)$ but not significantly higher than in the reaction without the presence of $\mathrm{NH}_{3} . \mathrm{NH}_{3}$ can considerably enhance the generation of SOAs in $\mathrm{O}_{3}$ and monoterpene reactions (Huang et al., 2012), and more organic matter with carbon was generated, which enhanced the carbon distribution of SOAs. The contribution of $\mathrm{N}$ increased by as much as $167 \%$ in the reactions of $\mathrm{O}_{3}$ and monoterpene without $\mathrm{NH}_{3}$ compared with the blank sample. The substantial growth of $\mathrm{N}$ indicated the transformation of gas-phase $\mathrm{N}$ into solid phase with new formation of organic particles. With the presence of $\mathrm{NH}_{3}$, the contribution of $\mathrm{N}$ element was $43.8 \%$ higher than in the reaction without $\mathrm{NH}_{3}$. The increase could be attributed to the positive effect of $\mathrm{NH}_{3}$ on the $\mathrm{O}_{3} /$ monoterpene reactions that enhanced the formation of SOAs, including nitrogen organic matter such as cyanide and organic matrix. A small quantity of $\mathrm{NH}_{3}$ adhered to the surface of the quartz filter in the reaction, which may have also contributed to the $\mathrm{N}$ increase.

The atomic ratio of elements has been widely used to analyze the chemistry of environmental matrices (Song and Huang, 2005; Shchukarev and Sjöberg, 2005; Qi et al., 2006). The O/C value of the blank sample (5.75) was substantially higher than that of $\mathrm{O}_{3}$ and monoterpene reactions with $\mathrm{NH}_{3}$ (4.31) and without $\mathrm{NH}_{3}$ (4.52). Large amounts of new organic matter were generated in the reaction, and the high ratio of carbon in the organic particles could have resulted in a decrease in the $\mathrm{O} / \mathrm{C}$ ratio. The declining trend of $\mathrm{O} / \mathrm{C}$ with the presence of $\mathrm{NH}_{3}$ may be because the continuously generated new organic particles enhanced the organic compound yields. The N/C value of the group without $\mathrm{NH}_{3}$ (0.122) increased compared with the blank sample (0.057), which was attributed to the compounds in the gas phase (including $\mathrm{NO}, \mathrm{NO}_{2}, \mathrm{~N}_{2} \mathrm{O}_{5}, \mathrm{HNO}_{3}, \mathrm{HONO}$, et al.) reacting with the BVOCs and generating large amounts of nitrogencontaining organic compounds in the solid phase. With the presence of $\mathrm{NH}_{3}$, the $\mathrm{N} / \mathrm{C}$ ratio could be as high as 0.172 . The atoms were more active due to the effect of $\mathrm{NH}_{3}$ in the reaction of $\mathrm{O}_{3}$ and monoterpene and enhanced the generation of nitrogen-containing organic compounds.

\section{Chemical States of Elements}

The high-resolution $\mathrm{O} 1 \mathrm{~s}, \mathrm{~N} 1 \mathrm{~s}$, and $\mathrm{C} 1 \mathrm{~s}$ spectrum of the filter samples from the $\mathrm{O}_{3}$ and monoterpene reactions with and without the presence of $\mathrm{NH}_{3}$ are shown in Fig. 3. The binding energy of $\mathrm{N} 1 \mathrm{~s}$ in samples with and without $\mathrm{NH}_{3}$ in the reactions of $\mathrm{O}_{3}$ and monoterpene were 399.8 and 399.6 $\mathrm{eV}$, respectively. The nitrogen-containing compounds could be $\mathrm{NH}_{3}$, cyanide, or an organic matrix; however, the exact percentage of each possible component is still unknown. As a result of the contribution from pyrrolic and amide nitrogen forms, some of the nitrogen in aerosol particles is assignable to amides, which was also shown by the $\mathrm{C} 1 \mathrm{~s}$ peak of $\mathrm{C}(\mathrm{O}) \mathrm{N}$ (Song and Peng, 2009). With the oxidation effect of $\mathrm{O}_{3}$, the nitrogen-containing gas-phase compounds (e.g., $\mathrm{N}_{2}$ and $\mathrm{NH}_{3}$ ) reacted with monoterpene, and the $\mathrm{C}-\mathrm{C}$ and $\mathrm{C}-\mathrm{H}$ resolved and formed new bonds such as $\mathrm{C}-\mathrm{N}$ and $\mathrm{C}(\mathrm{O}) \mathrm{N}$.

More than one chemical embedment was identified in the carbon spectrum. To quantify the high-energy tail of the $\mathrm{C} 1 \mathrm{~s}$ signal in detail, all particle sample carbon concentrations was classified into four types: (1) unsubstituted aromatic carbon (C-C/C-H, $283.8 \mathrm{eV}$ ), (2) aliphatic carbon (C-C/C-H, 284.8 $\mathrm{eV}),(3)$ amide carbon [C(O)N, $286.3 \mathrm{eV}]$, and (4) carboxylic carbon $[\mathrm{C}(\mathrm{O}) \mathrm{O}, 288.5 \mathrm{eV}]$ according to the $\mathrm{C} 1 \mathrm{~s}$ spectra (Monteil-Rivera et al., 2000). The chemical assignments and experimental area percentages for each component of the $\mathrm{C} 1 \mathrm{~s}$ spectra of the three samples are shown in Table 1. More 

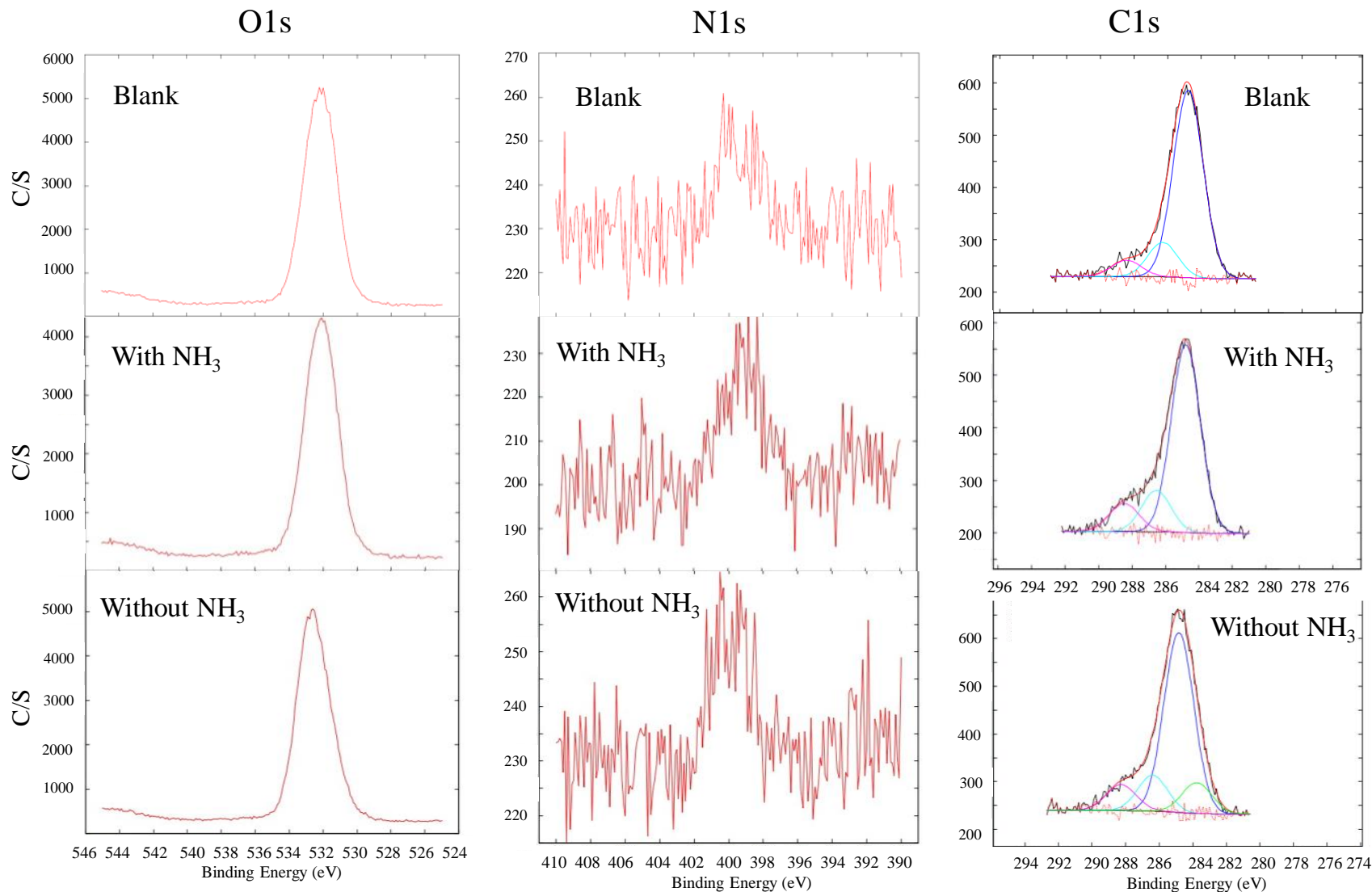

Fig. 3. High-resolution X-ray photoelectron spectrum of O1s, N1s, and C1s for SOAs.

Table 1. Percentage area (\%) for chemical peaks under the $\mathrm{C} 1 \mathrm{~s}$ envelopes.

\begin{tabular}{llllll}
\hline \multirow{2}{*}{ Possible compound } & Aromatic & Aliphatic & \multirow{2}{*}{ C-O/C-N } & \multirow{2}{*}{ COO } \\
\hline \multirow{2}{*}{ Atomic \% } & C-C/C-H & C-C/C-H & & \\
& Blank & - & 78.72 & 14.45 & 6.83 \\
& Without $\mathrm{NH}_{3}$ & 11.33 & 66.10 & 13.08 & 9.49 \\
& ${\text { With } \mathrm{NH}_{3}}$ & - & 72.92 & 16.01 & 11.07 \\
\hline
\end{tabular}

than $70 \%$ of the carbon was in $\mathrm{CH}$ state, and these $\mathrm{C}-\mathrm{H}$ functional groups included aromatic $\mathrm{C}-\mathrm{H}$ and aliphatic $\mathrm{C}-\mathrm{H}$. In the reaction without $\mathrm{NH}_{3}$, an aromatic hydrocarbon of $11.3 \%$ was observed in all the carbon-containing organic compounds. The original carbon structure of monoterpene, including aromatic $\mathrm{C}-\mathrm{H}$, was not completely separated by the reaction with $\mathrm{O}_{3}$. With the presence of $\mathrm{NH}_{3}$, no aromatic $\mathrm{C}-\mathrm{H}$ was observed in the SOAs, indicating that all monoterpenes in the reactions had transformed into aliphatic $\mathrm{C}-\mathrm{H}$ and other carbon-containing organic compounds. Studies have revealed that reactions of $\mathrm{O}_{3}$ with constituents containing unsaturated $\mathrm{C}-\mathrm{C}$ bonds are highly reactive and always serve as a larger source of secondary pollutants (Westbrook et al., 2013). The $\mathrm{O}_{3}$ and monoterpene in the chamber reacted rapidly and generated secondary pollutants by decomposing unsaturated $\mathrm{C}-\mathrm{C}$ bonds. This also explained the decreasing trend of $\mathrm{C}-\mathrm{C}$ and $\mathrm{C}-\mathrm{H}$ contribution after reaction. BVOCs are labile and can be oxidized in the atmosphere, thereby resulting in many oxygen-containing polar compounds aggregating on the surface of aerosol particles (Kroll and Seinfeld, 2008).
$\mathrm{CO} / \mathrm{CN}$ and $\mathrm{COO}$ structures were detected in the surface particles. The primary oxygen functional groups (i.e., carboxylic and phenolic moieties) can react with $\mathrm{O}_{3}$ and form secondary organic particles containing $\mathrm{CO} / \mathrm{CN}$ and $\mathrm{COO}$ functional groups. With the presence of $\mathrm{NH}_{3}$, more organic compounds in $\mathrm{CO} / \mathrm{CN}$ and $\mathrm{COO}$ structures were generated compared with the reactions without $\mathrm{NH}_{3}$, this may be attributed to the active atoms leading to the formation of new bonds in the reactions.

\section{Oxidative Stress Induced by SOAs}

Antioxidants (e.g., GSH) and antioxidant enzymes (e.g., SOD, glutathione peroxidase, and catalase) prevent the generation of ROS and subsequent oxidative damage to various cell constituents and can provide antioxidant defenses to the respiratory system (Blokhina et al., 2003). When an imbalance between excessive oxidant and antioxidant defenses exists, oxidative stress is triggered (Leeuwenburgh and Heinecke, 2001). The oxidative stress and antioxidative responses in mice BALF after exposure to $\mathrm{PM}_{2.5}$ from $\mathrm{O}_{3}$ 
and monoterpene reactions are presented in Fig. 4. The production of SOD, MDA, and GSH after exposure to samples generated with and without the presence of $\mathrm{NH}_{3}$ differed significantly compared with control groups $(\mathrm{p}<$ 0.05). The concentration of SOD declined significantly (55.9\% for the group without $\mathrm{NH}_{3}$ and $54.0 \%$ for the group with $\mathrm{NH}_{3}$ ) after $6 \mathrm{~h}$ of exposure to $\mathrm{PM}_{2.5}$ compared with the control group. No significant difference was observed between the group with and without the presence of $\mathrm{NH}_{3}$. GSH also exhibited a decreasing trend compared with the control group in the biomarker of antioxidation. After $6 \mathrm{~h}$ of exposure to $\mathrm{PM}_{2.5}$, the GSH concentrations of the groups with and without $\mathrm{NH}_{3}$ declined to 2.4 and $2.6 \mathrm{mg} \mathrm{g}^{-1}$ protein, respectively. The generation of MDA increased significantly compared with the control group, indicating that oxidative stress was triggered by $\mathrm{PM}_{2.5}$ in mice BALF. No significant
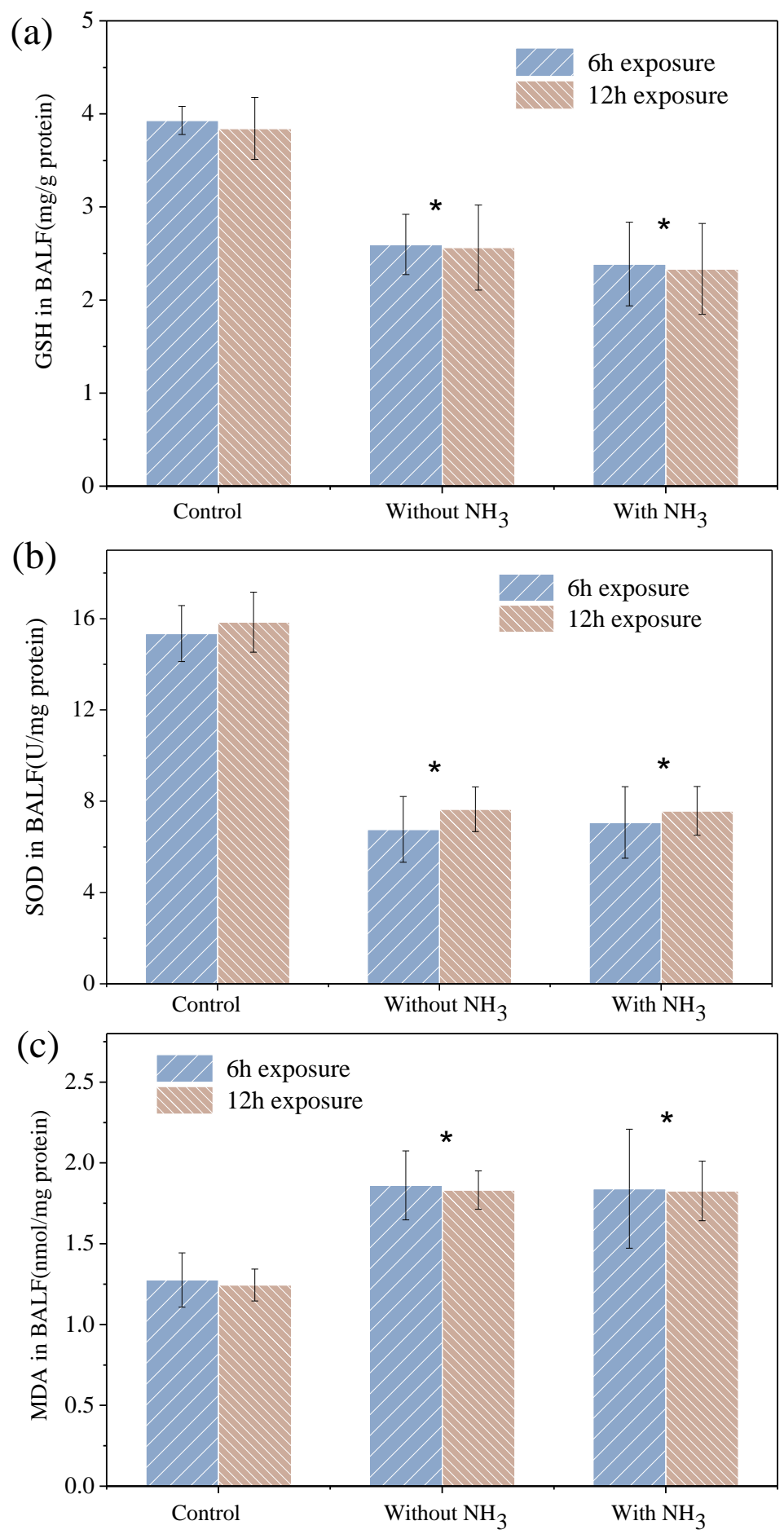

Fig. 4. Activity levels of (a) SOD, (b) MDA, and (c) GSH in BALF after mouse exposure to $\mathrm{PM}_{2.5}$ from $\mathrm{O}_{3}$ and monoterpene reactions. $* \mathrm{p}<0.05$ compared with the control group. 
difference was observed between the groups with and without $\mathrm{NH}_{3}$. It is inferred that the additional chemical compounds generated in $\mathrm{O}_{3}$ and monoterpene reactions with $\mathrm{NH}_{3}$ were not the main contributors to $\mathrm{PM}_{2.5}$-triggered oxidative reactions.

Oxidative stress has been confirmed as a common pathway for oxidative damage caused by $\mathrm{PM}_{2.5}$ (Bonetta et al., 2009). The generation of free radicals and oxidative stress would further indicate that the occurrence of inflammatory responses in the human respiratory systems is associated with $\mathrm{PM}_{2.5}$ exposure (Dilger et al., 2016). In our study, the SOAs generated from the reactions of $\mathrm{O}_{3}$ and monoterpene caused oxidative stress in mice lungs with short-term exposure. The differences in oxidative stress levels in different reaction groups are associated with the chemical compositions of $\mathrm{PM}_{2.5}$, especially organic components (Gualtieri et al., 2009; Ho et al., 2016a). The oxygen-containing polar compounds in SOAs generated from $\mathrm{O}_{3}$ and monoterpene reactions were important contributors to the oxidative responses. The oxidative stress in mice BALF could be triggered by different sources, including (1) the direct generation of ROS on the surface of the particle, (2) Fenton reactions with transition metals and organic compounds, (3) the activation of inflammatory cells able to generate ROS and reactive nitrogen species, and (4) alteration in mitochondrial function or NADPH oxidase (Risom et al., 2005; Lakey et al., 2016). The compounds generated in $\mathrm{O}_{3}$ and monoterpene reactions that collected on the filter including various chemical compounds would cause oxidative stress via different pathways. Riva et al. (2011) revealed that low doses of PM could induce lung oxidative stress, inflammation, and worsened lung impedance and histology in mice. Rohr et al. (2002) suggested that oxidation products of ozone and unsaturated hydrocarbons may have medium-term adverse effects on the upper airways and pulmonary regions. A related study confirmed upper airway irritation in mice and a reduction of respiratory rate after exposure to a mixture of terpenes and $\mathrm{O}_{3}$ (Rohr et al., 2002).

Our results indicated that short-term exposure to $\mathrm{PM}_{2.5}$ from $\mathrm{O}_{3}$ and monoterpene reactions induced the inhibition of antioxidant enzymatic activities of SOD and antioxidant generation of GSH. Longer exposure time induced more considerable reductions of GSH, whereas time-related responses for SOD and GSH were not significant due to the relatively short exposure time in this study. The group with $\mathrm{NH}_{3}$ exhibited lower GSH levels compared with the group without $\mathrm{NH}_{3}$, indicating the relatively higher oxidative ability of SOAs from reactions with the presence of $\mathrm{NH}_{3}$. More organic compounds with $\mathrm{C}-\mathrm{C} / \mathrm{C}-\mathrm{H}, \mathrm{C}-\mathrm{O} / \mathrm{C}-\mathrm{N}$, and $\mathrm{COO}$ function groups were generated with the addition of $\mathrm{NH}_{3}$ reaction, which could be responsible for the elevated oxidative stress. SOD could catalyze the dismutation of $\mathrm{O}_{2}{ }^{-}$ to $\mathrm{H}_{2} \mathrm{O}_{2}$, which protects cells from oxidation ( $\mathrm{Go}$ and $\mathrm{Kim}$, 2001). The ROS induced by $\mathrm{PM}_{2.5}$ in mice lungs can interact directly with antioxidant enzymes, which would further cause a reduction in enzymatic activities (Pamplona and Costantini, 2011). The excessive generation of ROS in radical form causes severe damage to DNA, RNA, and proteins in the respiratory system (Vattanasit et al., 2014). These results are in agreement with the study indicating that $\mathrm{PM}_{2.5}$ can elicit oxidative stress by inducing ROS generation and causing a loss of antioxidant enzymatic activity (Deng et al., 2013). The decline in GSH levels after exposure to $\mathrm{PM}_{2.5}$ from $\mathrm{O}_{3}$ and monoterpene reactions is probably caused by a GSH peroxidase reaction, GSH transferase reaction, or GSH efflux (Riva et al., 2011). Our results were in agreement with the study in which pulmonary inflammation was caused by $\mathrm{PM}$ exposure in the airways of neonate rats, which also reported a diminished GSH related to the inflammatory process (Ding et al., 2010). Weldy et al. (2011) confirmed that GSH synthesis can mediate diesel exhaust particulate-induced lung inflammation through mice exposure experiments.

With the inhibition of SOD as antioxidative enzymes in oxidative stress conditions in mice BALF, the excessive ROS easily attack the cell membrane and form MDA (Gehling et al., 2014). MDA is a product of ROS-mediated lipid peroxidation and has been used as the biomarker for cell membrane damage (Bo et al., 2016). In our study, MDA concentrations in different reaction groups increased significantly after exposure to $\mathrm{PM}_{2.5}$ extractions. The SOAs generated from $\mathrm{O}_{3}$ and monoterpene reactions could cause oxidative stress in the pulmonary system of mice and damage cell membranes. Exposure to the SOAs led to an imbalance of pro-oxidants and antioxidants in mice BALF and resulted in the occurrence of oxidative stress (Dianat et al., 2016). With the reactions of $\mathrm{O}_{3}$ and monoterpene, the generation of organic compounds in SOAs including $\mathrm{C}-\mathrm{O} / \mathrm{C}-\mathrm{N}$ and $\mathrm{COO}$ functional groups enhanced the damage to cell membranes. The effect of SOAs from reactions with and without the presence of $\mathrm{NH}_{3}$ did not reveal significant differences. This may be due to the slight differences in the $\mathrm{PM}_{2.5}$ chemical compositions from reactions with and without the presence of $\mathrm{NH}_{3}$. This indicates that $\mathrm{NH}_{3}$ did not strongly affect the acute respiratory oxidative damage caused by $\mathrm{O}_{3}$ and monoterpene reactions. The release of MDA caused by $\mathrm{PM}_{2.5}$ exposure did not show significant time-dependent responses. Li et al. (2015) revealed that the changes of mitochondrial fission induced by $\mathrm{PM}_{2.5}$ exposure were accompanied by an increase in MDA. A related study on the toxicity of $\mathrm{PM}_{2.5}$ revealed oxidative damage to human alveolar epithelia cells through the induction of lipid peroxidation and the alteration of MDA activity (Kouassi et al., 2010).

\section{CONCLUSION}

This study investigated the ozone-initiated formation of indoor SOAs containing monoterpene in a large environmental chamber and their corresponding respiratory health effects. The presence of $\mathrm{NH}_{3}$ potentially enhanced the formation of SOAs from reactions between $\mathrm{O}_{3}$ and monoterpene and also altered the surface characteristics of these SOAs. More organic compounds with $\mathrm{C}-\mathrm{N}$ and $\mathrm{COO}$ functional groups were also generated when $\mathrm{NH}_{3}$ was present during the reactions. Furthermore, we examined oxidative stress in the BALF of mice following exposure to these SOAs. The antioxidant and oxidative biomarkers displayed no significant differences between the groups with and without $\mathrm{NH}_{3}$, indicating that $\mathrm{NH}_{3}$ exerts no distinct influence through the generated SOAs on acute lung injury in mice. 


\section{REFERENCES}

Atzei, D. and Rossi, A. (2004). Quantitative surface analysis of urban airborne particles by X-ray photoelectron spectroscopy. Anal. Chim. 94: 123-133. https://doi.org/10. 1002/adic.200490016

Blokhina, O., Virolainen, E. and Fagerstedt, K.V. (2003). Antioxidants, oxidative damage and oxygen deprivation stress: A review. Ann. Bot. 91: 179-194. https://doi.org/1 $0.1093 / \mathrm{aob} / \mathrm{mcf} 118$

Bo, L., Jiang, S., Xie, Y., Kan, H., Song, W. and Zhao, J. (2016). Effect of vitamin $E$ and omega-3 fatty acids on protecting ambient $\mathrm{PM}_{2.5}$-induced inflammatory response and oxidative stress in vascular endothelial cells. PLOS One 11: e0152216. https://doi.org/10.1371/journal.pone. 0152216

Bonetta, S., Gianotti, V., Bonetta, S., Gosetti, F., Oddone, M., Gennaro, M.C. and Carraro, E. (2009). DNA damage in A549 cells exposed to different extracts of $\mathrm{PM}_{2.5}$ from industrial, urban and highway sites. Chemosphere 77: 1030-1034. https://doi.org/10.1016/j.chemosphere.2009. 07.076

Chen, X. and Hopke, P.K. (2010). A chamber study of secondary organic aerosol formation by limonene ozonolysis. Indoor Air 20: 320-328. https://doi.org/10.11 11/j.1600-0668.2010.00656.x

Cheng, W., Weng, L.T., Li, Y., Lau, A., Chan, C.K., Chan, C.M. (2013). Surface chemical composition of sizefractionated urban walkway aerosols determined by X-ray photoelectron spectroscopy. Aerosol Sci. Technol. 47: 11181124. https://doi.org/10.1080/02786826.2013.824066

Chuang, H.C., Jones, T., Chen, T.T. and BeruBe, K. (2013). Cytotoxic effects of incense particles in relation to oxidative stress, the cell cycle and F-actin assembly. Toxicol. Lett. 220: 229-237. https://doi.org/10.1016/j.tox let.2013.05.004

Colbeck, I., Nasir, Z.A. and Ali, Z. (2010). Characteristics of indoor/outdoor particulate pollution in urban and rural residential environment of Pakistan. Indoor Air 20: 40 51. https://doi.org/10.1111/j.1600-0668.2009.00624.x

Coleman, B.K., Lunden, M.M., Destaillats, H. and Nazaroff, W.W. (2008). Secondary organic aerosol from ozoneinitiated reactions with terpene-rich household products. Atmos. Environ. 42: 8234-8245. https://doi.org/10.1016/ j.atmosenv.2008.07.031

Daher, N., Saliba, N.A., Shihadeh, A.L., Jaafar, M., Baalbaki, R., Shafer, M.M., Schauer, J.J. and Sioutas, C. (2014). Oxidative potential and chemical speciation of size-resolved particulate matter (PM) at near-freeway and urban background sites in the greater Beirut area. Sci. Total Environ. 470: 417-426. https://doi.org/10.1016/j.sc itotenv.2013.09.104

Deng, X., Zhang, F., Rui, W., Long, F., Wang, L., Feng, Z., Chen, D. and Ding, W. (2013). PM $_{2.5}$-induced oxidative stress triggers autophagy in human lung epithelial A549 cells. Toxicol. in Vitro 27: 1762-1770. https://doi.org/10. 1016/j.tiv.2013.05.004

Dianat, M., Radmanesh, E., Badavi, M., Goudarzi, G. and Mard, S.A. (2016). The effects of $\mathrm{PM}_{10}$ on electrocardiogram parameters, blood pressure and oxidative stress in healthy rats: The protective effects of vanillic acid. Environ. Sci. Pollut. Res. 23: 19551-19560. https://doi.org/10.1007/s11356-016-7168-1

Dieme, D., Cabral-Ndior, M., Garcon, G., Verdin, A., Billet, S., Cazier, F., Courcot, D., Diouf, A. and Shirali, P. (2012). Relationship between physicochemical characterization and toxicity of fine particulate matter $\left(\mathrm{PM}_{2.5}\right)$ collected in Dakar city (Senegal). Environ. Res. 113: 1-13. https://doi.org/10.1016/j.envres.2011.11.009

Dilger, M., Orasche, J., Zimmermann, R., Paur, H.R., Diabate, S. and Weiss, C. (2016). Toxicity of wood smoke particles in human A549 lung epithelial cells: The role of PAHs, soot and zinc. Arch. Toxicol. 90: 3029-3044. https://doi.org/10.1007/s00204-016-1659-1

Ding, L.R., Kai, W., Fahmy, B., Shen, H.H. and Stephania, C. (2010). Airborne fine particulate matter induced pulmonary inflammation as well as oxidative stress in neonate rats. Chin. Med. J. 123: 2895-2900.

Gehling, W., Khachatryan, L. and Dellinger, B. (2014). Hydroxyl radical generation from environmentally persistent free radicals (EPFRs) in $\mathrm{PM}_{2.5}$. Environ. Sci. Technol. 48: 4266-4272. https://doi.org/10.10/21/es401770y

Go, M.J. and Kim, H.J. (2001). the effect of metallothionein on the activity of enzymes invelved in remival of reactive oxygen species. Bull. Korean Chem. Soc. 22: 362-366. http://www.koreascience.or.kr/article/JAKO2001134644 78368.page

Gualtieri, M., Mantecca, P., Corvaja, V., Longhin, E., Perrone, M.G., Bolzacchini, E. and Camatini, M. (2009). Winter fine particulate matter from Milan induces morphological and functional alterations in human pulmonary epithelial cells (A549). Toxicol. Lett. 188: 5262. https://doi.org/10.1016/j.toxlet.2009.03.003

Hallquist, M., Wenger, J.C., Baltensperger, U., Rudich, Y., Simpson, D., Claeys, M., Dommen, J., Donahue, N., George, C. and Goldstein, A. (2009). The formation, properties and impact of secondary organic aerosol: Current and emerging issues. Atmos. Chem. Phys. 9: 5155-5236. https://doi.org/10.5194/acp-9-5155-2009

Ho, K.F., Chang, C.C., Tian, L., Chan, C.S., Musa Bandowe, B.A., Lui, K.H., Lee, K.Y., Chuang, K.J., Liu, C.Y., Ning, Z. and Chuang, H.C. (2016a). Effects of polycyclic aromatic compounds in fine particulate matter generated from household coal combustion on response to EGFR mutations in vitro. Environ. Pollut. 218: 1262-1269. https://doi.org/10.1016/j.envpol.2016.08.084

Ho, K.F., Ho, S.S.H., Huang, R.J., Chuang, H.C., Cao, J.J., Han, Y., Lui, K.H., Ning, Z., Chuang, K.J., Cheng, T.J., Lee, S.C., Hu, D., Wang, B. and Zhang, R. (2016b). Chemical composition and bioreactivity of $\mathrm{PM}_{2.5}$ during 2013 haze events in China. Atmos. Environ. 126: 162170. https://doi.org/10.1016/j.atmosenv.2015.11.055

Huang, Y., Ho, S.S.H., Ho, K.F., Lee, S.C., Gao, Y., Cheng, Y. and Chan, C. (2011). Characterization of biogenic volatile organic compounds (BVOCs) in cleaning reagents and air fresheners in Hong Kong. Atmos. Environ. 45: 61916196. https://doi.org/10.1016/j.atmosenv.2011.08.012

Huang, Y., Lee, S.C., Ho, K.F., Ho, S.S.H., Cao, N.Y., 
Cheng, Y. and Gao, Y. (2012). Effect of ammonia on ozone-initiated formation of indoor secondary products with emissions from cleaning products. Atmos. Environ. 59: 224-231. https://doi.org/10.1016/j.atmosenv.2012.04.059

Kappos, A.D., Bruckmann, P., Eikmann, T., Englert, N., Heinrich, U., Höppe, P., Koch, E., Krause, G.H., Kreyling, W.G. and Rauchfuss, K. (2004). Health effects of particles in ambient air. Int. J. Hyg. Environ. Health 207: 399-407. https://doi.org/10.1078/1438-4639-00306

Kim, C.S. and Hu, S. (1998). Regional Deposition of inhaled particles in human lungs: Comparison between men and women. J. Appl. Physiol. 84: 1834-1844. https://doi.org/ 10.1152/jappl.1998.84.6.1834

Kim, K.H., Kabir, E. and Kabir, S. (2015). A review on the human health impact of airborne particulate matter. Environ. Int. 74: 136-143. https://doi.org/10.1016/j.envi nt.2014.10.005

Kouassi, K.S., Billet, S., Garçon, G., Verdin, A., Diouf, A., Cazier, F., Djaman, J., Courcot, D. and Shirali, P. (2010). Oxidative damage induced in A549 cells by physically and chemically characterized air particulate matter $\left(\mathrm{PM}_{2.5}\right)$ collected in Abidjan, Côte d'Ivoire. J. Appl. Toxicol. 30: 310-320. https://doi.org/10.1002/jat.1496

Kroll, J.H. and Seinfeld, J.H. (2008). Chemistry of secondary organic aerosol: Formation and evolution of low-volatility organics in the atmosphere. Atmos. Environ. 42: 35933624. https://doi.org/10.1016/j.atmosenv.2008.01.003

Lakey, P.S., Berkemeier, T., Tong, H., Arangio, A.M., Lucas, K., Pöschl, U. and Shiraiwa, M. (2016). Chemical exposure-response relationship between air pollutants and reactive oxygen species in the human respiratory tract. Sci. Rep. 6: 32916. https://doi.org/10.1038/srep32916

Langer, S., Moldanová, J., Arrhenius, K., Ljungström, E. and Ekberg, L. (2008). Ultrafine particles produced by ozone/limonene reactions in indoor air under low/closed ventilation conditions.. Atmos. Environ. 42: 4149-4159. https://doi.org/10.1016/j.atmosenv.2008.01.034

Leeuwenburgh, C. and Heinecke, J. (2001). Oxidative stress and antioxidants in exercise. Curr. Med. Chem. 8: 829838. https://doi.org/10.2174/0929867013372896

Li, R., Kou, X., Geng, H., Xie, J., Tian, J., Cai, Z. and Dong, C. (2015). Mitochondrial damage: An important mechanism of ambient $\mathrm{PM}_{2.5}$ exposure-induced acute heart injury in rats. J. Hazard. Mater. 287: 392-401. https://doi.org/10.1 016/j.jhazmat.2015.02.006

Matsumoto, J. (2014). Measuring biogenic volatile organic compounds (BVOCs) from vegetation in terms of ozone reactivity. Aerosol Air Qual. Res. 14: 197-206. https://doi.org/10.4209/aaqr.2012.10.0275

McDonald, J.D., Doyle-Eisele, M., Kracko, D., Lund, A., Surratt, J.D., Hersey, S.P., Seinfeld, J.H., Rohr, A.C. and Knipping, E.M. (2012). Cardiopulmonary response to inhalation of secondary organic aerosol derived from gasphase oxidation of toluene. Inhalation Toxicol. 24: 689697. https://doi.org/10.3109/08958378.2012.712164

Monteil-Rivera, F., Brouwer, E.B., Masset, S., Deslandes, Y. and Dumonceau, J. (2000). Combination of X-ray photoelectron and solid-state ${ }^{13} \mathrm{C}$ nuclear magnetic resonance spectroscopy in the structural characterisation of humic acids. Anal. Chim. Acta 424: 243-255. https://doi.org/10.1016/S0003-2670(00)01139-9

Morawska, L., Afshari, A., Bae, G., Buonanno, G., Chao, C., Hänninen, O., Hofmann, W., Isaxon, C., Jayaratne, E. and Pasanen, P. (2013). Indoor aerosols: From personal exposure to risk assessment. Indoor Air 23: 462-487. https://doi.org/10.1111/ina.12044

Moron, M.S., Depierre, J.W. and Mannervik, B. (1979). Levels of glutathione, glutathione reductase and glutathione $S$-transferase activities in rat lung and liver. Biochim. Biophys. Acta, Gen. Subj. 582: 67-78. https://doi.org/10.1016/0304-4165(79)90289-7

Na, K., Song, C., Switzer, C. and Cocker, D.R. (2007). Effect of ammonia on secondary organic aerosol formation from alpha-pinene ozonolysis in dry and humid conditions. Environ. Sci. Technol. 41: 6096-6102. https://doi.org/10.1021/es061956y

Niu, X., Ho, S.S.H., Ho, K.F., Huang, Y., Sun, J., Wang, Q., Zhou, Y., Zhao, Z. and Cao, J. (2017). Atmospheric levels and cytotoxicity of polycyclic aromatic hydrocarbons and oxygenated-PAHs in $\mathrm{PM}_{2.5}$ in the Beijing-Tianjin-Hebei region. Environ. Pollut. 231: 1075-1084. https://doi.org/ 10.1016/j.envpol.2017.08.099

Nørgaard, A., Kudal, J., Kofoed-Sørensen, V., Koponen, I. and Wolkoff, P. (2014). Ozone-initiated VOC and particle emissions from a cleaning agent and an air freshener: Risk assessment of acute airway effects. Environ. Int. 68: 209218. https://doi.org/10.1016/j.envint.2014.03.029

Oh, S.M., Kim, H.R., Park, Y.J., Lee, S.Y. and Chung, K.H. (2011). Organic extracts of urban air pollution particulate matter $\left(\mathrm{PM}_{2.5}\right)$-induced genotoxicity and oxidative stress in human lung bronchial epithelial cells (BEAS-2B cells). Mutat. Res. Genet. Toxicol. Environ. Mutagen. 723: 142151. https://doi.org/10.1016/j.mrgentox.2011.04.003

Pamplona, R. and Costantini, D. (2011). Molecular and structural antioxidant defenses against oxidative stress in animals. Am. J. Physiol. Regul. Integr. Comp. Physiol. 301: R843-R863. https://doi.org/10.1152/ajpregu.00034. 2011

Pei, J.J., Yin, Y.H., Liu, J.J. (2016). Long-termindoor gas pollutantmonitor of newdormitories with natural ventilation. Energy Build. 129: 514-523. https://doi.org/ 10.1016/j.enbuild.2016.08.033

Perrino, C., Tofful, L. and Canepari, S. (2016). Chemical characterization of indoor and outdoor fine particulate matter in an occupied apartment in Rome, Italy. Indoor Air 26: 558-570. https://doi.org/10.1111/ina.12235

Risom, L., Møller, P. and Loft, S. (2005). Oxidative stressinduced DNA damage by particulate air pollution. Mutat. Res. Genet. Toxicol. Environ. Mutagen. 592: 119-137. https://doi.org/10.1016/j.mrfmmm.2005.06.012

Riva, D., Magalhaes, C., Lopes, A.A., Lancas, T., Mauad, T., Malm, O., Valenca, S., Saldiva, P., Faffe, D. and Zin, W. (2011). Low dose of fine particulate matter $\left(\mathrm{PM}_{2.5}\right)$ can induce acute oxidative stress, inflammation and pulmonary impairment in healthy mice. Inhalation Toxicol. 23: 257267. https://doi.org/10.3109/08958378.2011.566290

Rohr, A.C., Wilkins, C.K., Clausen, P.A., Hammer, M., Nielsen, G.D., Wolkoff, P. and Spengler, J.D. (2002). 
Upper airway and pulmonary effects of oxidation products of $(+)-\alpha$-pinene, $d$-limonene, and isoprene in $\mathrm{BALB} / \mathrm{c}$ mice. Inhalation Toxicol. 14: 663-684. https://doi.org/10.1080/08958370290084575

Shen, H. and Anastasio, C. (2011). Formation of hydroxyl radical from San Joaquin Valley particles extracted in a cell-free surrogate lung fluid. Atmos. Chem. Phys. 11: 9671-9682. https://doi.org/10.5194/acp-11-9671-2011

Song, J. and Huang, W. (2005). Characterization of humic acid-like material isolated from the humin fraction of a topsoil. Soil Sci. 170: 599-611. https://doi.org/10.1590/0 1000683 rbcs 20150294

Song, J. and Peng, P. (2009). Surface characterization of aerosol particles in Guangzhou, China: A study by XPS. Aerosol Sci. Technol. 43: 1230-1242. https://doi.org/10.1 080/02786820903325394

Vattanasit, U., Navasumrit, P., Khadka, M.B., Kanitwithayanun, J., Promvijit, J., Autrup, H. and Ruchirawat, M. (2014). Oxidative DNA damage and inflammatory responses in cultured human cells and in humans exposed to traffic-related particles. Int. J. Hyg. Environ. Health 217: 23-33. https://doi.org/10.1016/j.ijh eh.2013.03.002

Wang, B., Liu, Y., Shao, M., Lu, S., Wang, M., Yuan, B., Gong, Z., He, L., Zeng, L. and Hu, M. (2016). The contributions of biomass burning to primary and secondary organics: A case study in Pearl River Delta (PRD), China. Sci. Total Environ. 569: 548-556. https://doi.org/10.1016 /j.scitotenv.2016.06.153

Waring, M.S. and Siegel, J.A. (2013). Indoor secondary organic aerosol formation initiated from reactions between ozone and surface-sorbed D-limonene. Environ. Sci.
Technol. 47: 6341-6348. https://doi.org/10.1021/es400846d Weldy, C.S., White, C.C., Wilkerson, H.W., Larson, T.V., Stewart, J.A., Gill, S.E., Parks, W.C. and Kavanagh, T.J. (2011). Heterozygosity in the glutathione synthesis gene Gclm increases sensitivity to diesel exhaust particulate induced lung inflammation in mice. Inhalation Toxicol. 23: 724-735. https://doi.org/10.3109/08958378.2011.60 8095

Weschler, C.J. (2006). Ozone's impact on public health: contributions from indoor exposures to ozone and products of ozone-initiated chemistry. Environ. Health Perspect. 114: 1489-1496. https://doi.org/10.1289/ehp.9256

Westbrook, C., Pitz, W., Sarathy, S. and Mehl, M. (2013). Detailed chemical kinetic modeling of the effects of CC double bonds on the ignition of biodiesel fuels. Proc. Combust. Inst. 34: 3049-3056. https://doi.org/10.1016/j.p roci.2012.05.025

Yi, S., Zhang, F., Qu, F. and Ding, W. (2014). Waterinsoluble fraction of airborne particulate matter $\left(\mathrm{PM}_{10}\right)$ induces oxidative stress in human lung epithelial A549 cells. Environ. Toxicol. 29: 226-233. https://doi.org/10.1 002/tox. 21750

Yuan, B., Hu, W., Shao, M., Wang, M., Chen, W., Lu, S., Zeng, L. and Hu, M. (2013). VOC emissions, evolutions and contributions to SOA formation at a receptor site in eastern China. Atmos. Chem. Phys. 13: 8815-8832. https://doi.org/10.5194/acp-13-8815-2013

Received for review, December 13, 2019

Revised, April 1, 2020

Accepted, April 2, 2020 